\title{
Attraction factors into space as a required element of physical learning environment. A review
}

Jesus Miguel Munoz Cantero ${ }^{\mathrm{a}}$,

Ricardo García Mira ${ }^{b}$,

Vicente Lopez-Chaoc,

Suggested Citation:

New Trends and Issues Proceedings on Humanities and Social

Sciences.

Abstract

Jesus Miguel Munoz Cantero,

E-mail address 
1. Background

2. The lack of attachment to the educational space 


\section{Atracttion factors into space}

\subsection{ICT}


New Trends and Issues Proceedings on Humanities and Social Sciences.

3.2. Nature

133 


\subsection{Security, privacy and appropriation of space}

\section{Conclusion}


New Trends and Issues Proceedings on Humanities and Social Sciences.

\section{References}

\section{Management}

Total Quality 
New Trends and Issues Proceedings on Humanities and Social Sciences.

Converge.

- Revista Científica de Educomunicacion

Journal of educational administration

Learning Environments: Where Space, Technology, and Culture

Education Journal

Research in Higher ed.).

(5th Ed.).

Enhancing adult motivation to learn: a comprehensive guide for teaching all adults (3rd Service Marketing: Integrating Customer Focus Across the Firm 